\title{
Transitions and Re-engagement through Second Chance Education
}

\author{
Sharon Ross and Jan Gray \\ Edith Cowan University
}

\begin{abstract}
The issue of school non-completion continues to be a matter of concern for policy makers and practitioners in Australia today. Despite the efforts of governments and school systems to improve participation and retention rates, often one in three students drop out of school before completing Year 12. Major factors influence non-completion and militate against young people remaining at school. Findings from recent research indicate that some non-completers choose to re-enter education through second chance programs outside the school environment. The argument for second chance education presented in this paper is developed within the context of the 'risk' society and in relation to recent theories of youth transitions.
\end{abstract}

The need for a 'second chance' is justified in relation to recent theories of youth transitions, which suggest that re-entry into second chance education is a personal act of agency through which young people struggle to reclaim successful personal and educational identities amidst the constraints and hazards in their daily lives. Based on the findings that increasing numbers of non-completers are enrolling in TAFE second chance programs, these enabling programs are considered as a means of addressing the needs of this cohort. Educational policy in Australia related to second chance education is critically examined in light of international programs and recommendations for change are made.

\section{Introduction}

In the context of recent studies on non-completion of school and contemporary theories of youth transitions the relevance of second chance education in Australia is worthy of re-consideration. In May 2001, 31.85\% of 15 to 24 year olds enrolled in secondary school in the previous year were non-completers. This translates into 86,000 of the total 270,000-student population (ABS 2001). In recent years there has 
been no significant change in the numbers of non-completers, which are proportionately high compared to other OECD countries. As a group they persist and continue to be a source of concern to educational policy makers and practitioners (Lamb, Dwyer \& Wyn 2000, Lamb, Long \& Baldwin 2002, Lamb, Walstab, Teese, Vickers \& Rumberger 2004).

Research has established that the number of years of education and/or training is a significant predictor of future employment. In the case of non-completers, their vulnerability to economic and social change is greater because of their limited amount of schooling (Business Council of Australia 2003, Lamb et al 2000, Lamb et al 2004, Lamb \& McKenzie 2001, Lamb \& Rumberger 1999, McMillan \& Marks 2003). Ignored for the most part by policy makers, this small but socially significant group of young people are through their own volition seeking re-entry into education through second chance programs in TAFE (technical and further education) and ACE (adult community education) settings. Recent findings from a small body of literature show that many of these young people successfully complete a second chance or 'enabling' course and make effective transitions to further education and/or employment (Dawe 2004, Ferber 1999, McFadden 1996, Phan \& Ball 2001, Smyth \& Hattam 2004, Spierings 2003, Te Riele 2000, Wyn, Stokes \& Tyler 2004).

The notion of 'second chance' is strongly supported by recent theories of transition in the field of youth studies research. The traditional, linear, uni-dimensional models based on age or school to work transition are considered inadequate as they fail to capture the complexities of youth transitions in the post-modern era. Recent views of youth transitions as multidimensional, circular processes are gaining prominence. They include other kinds of transition such as moving away from home, movement from one relationship to the next, changes in life styles and transitions from single to parental status. Transition is perceived to be a fluid state, of always becoming, of arrival and departure, of leaving and re-entering education (Wyn et al 2004, Wyn \&White 1997). In this context, rejection of first chance education does not always represent closure. For many non-completers re-entry into second chance education is linked with the notion of education as 'unfinished business' (Munns \& McFadden 2000) and is an acknowledgement that they still had to complete a significant part of their education outside the school environment (Munns \& McFadden 2000, Smyth \& Hattam 2004, Wyn et al 2004).

In advancing the concept of second chance education and foregrounding notions of re-entry and re-engagement in relation to non-completers it is the purpose of this paper to open up current educational policy discourse in Australia that hitherto and to a large extent still is preoccupied with improving retention and linear school to work transitions. A useful starting point is the analysis of the key factors that influence 
non-completion, which provides the context for this discussion on re-engagement through second chance education.

\section{Defining the term 'non-completer'}

For the purposes of this paper and consistent with current research a 'non- completer' refers to any student who has not completed Year 12. Included in this group are the early school leavers, who leave before or at the end of Year 10, and the late school leavers, who leave at the end of Year 11 as well as those who drop out during Year 12 without attaining secondary graduation (Lamb et al 2000).

\section{Factors influencing non-completion}

Although the main factors that influence an individual's decision to drop out of school are presented separately in the ensuing discussion they have not been ranked, as it is usually the cumulative effect of a combination of factors that finally prompt a student to leave (Audas \& Williams 2001, Entwisle, Alexander \& Olsen 1997, Lamb et al 2004, McFadden 1996, Munns \& McFadden 2000, Wyn et al 2004). Consistent findings from a large body of research from the US, the UK, Canada and Australia highlight the influence of particular factors on non-completion.

\section{Socio-economic status: Parental occupation and parental education}

Family circumstances are shown to have a profound effect on educational achievement. The likelihood of non-completion is found to be greater among children from lower SES (socio-economic status) backgrounds where the parents are often in unskilled work, have a limited amount of formal schooling and a low level of income (Ainley \& Sheret 1992, Lamb et al 2000, Lamb et al 2004, McMillan \& Marks 2003, Rumberger \& Larson 1998). Both US data (Rumberger 2001) and Australian data (Gray \& Beresford 2001) suggest that residential and school mobility (changing residences and schools) increase the risk of dropping out of school and both have their roots in family poverty. Responsibilities for the care of younger siblings and having to contribute to the family economy through paid or unpaid work are also barriers to completion (Gray \& Beresford 2002, Wyn \& White 1997).

It is argued that children from low SES families start school from an inferior position and over time the achievement gap widens. With the gradual erosion of academic self-esteem they adjust their educational aspirations to gaining job-related skills while their more privileged peers focus on entry into university (Alexander, Entwisle \& Olsen 2001, Teese \& Polesel 2003). This is confirmed by findings from the Queensland study, which suggest that most well-to-do students from private schools 
assumed that they would get a university degree. In contrast, students from a working class background aimed at entering into an apprenticeship or the workforce (Pitman \& Herschell 2002).

The persistence of this trend is noted in the 2004 report prepared for The Smith Family using LSAY 1995 data (Longitudinal Survey of Australian Youth). Even when parents have a degree or diploma, students from the highest quintile of family socioeconomic status have a higher probability of planning full-time study, post-school. Of note is the $10 \%$ difference between the highest and lowest quintiles. Around $40 \%$ of students from the lowest quintile of family socio-economic status plan full time study, post-school, compared with over $50 \%$ of students from the highest quintile (Beavis, Murphy, Bryce \& Corrigan 2004). Thus the probability of planning to study full time after leaving school is seen to increase as the levels of parental socio-economic status rise.

\section{Family structure}

Until recently human capital (parental education) and financial capital (parental income) were seen to exert a powerful influence on dropping out of school. Findings from recent studies in the US indicate that family structure is also a predictor of drop out behaviour independent of socio-economic status. Students from single-parent and step families were found to be at greater risk of dropping out of school. Thus, the importance of social capital (family relationships and parental involvement) is also shown to be a significant determinant in reducing the odds of dropping out of school (Astone \& McLanahan 1991, Carbonaro 1998, Coleman 1988, Ekstrom, Goertz, Pollack \& Rock 1986, Goldschmidt \& Wang 1999, McNeal 1999, Rumberger 1983, Rumberger 1995, Rumberger \& Larson 1998, Swanson \& Sneider 1999, Teachman, Paasch, \& Carver 1996).

\section{Gender}

Studies on non-completion of schooling have shown a marked gender difference with higher rates of non-completion among boys. One reason advanced is that girls outperform boys in particular subjects (Arnot, Gray, James, Rudduck \& Duveen 1998, MacDonald, Saunders \& Benefield 1999, Sukhnandan 1999). Other researchers attribute this gap to changes in and awareness of gender segregation in the youth labour market. A dramatic decline in the teenage labour market has seen a sharp fall from 65\% employment in 1966 to $20 \%$ by the mid-1990s. Females fared worse than males (Lewis \& Koshy 1999, Wooden 1996). The continuing gender segregation of the labour market is further reflected in the overwhelming male domination of apprenticeships (Karmel 1995). The point to be noted is that it is not the 'pull' factors that cause girls to remain at school but rather the serious barriers they face at the point of entry into the workforce (Lamb \& McKenzie 2001). However compared to 
twenty-five years ago there has been a noticeable improvement in the career prospects for girls especially in the services sector and nursing. Entry into these professions requires a higher-level qualification, which is seen to have influenced higher levels of female school participation (Teese \& Polesel 2003).

\section{Language background}

Research conducted in Australia and reports from the US indicate that young people from language backgrounds other than English have a higher Year 12 completion rate compared to those from English-speaking backgrounds. Findings from a national longitudinal study of nine broad ethnic groups in Australia indicated that for each of the groups, the Year 12 participation rates were greater than those of students from English-speaking backgrounds (Marks, Fleming, Long \& McMillan 2000, McMillan \& Marks 2003). In both Australia and the US it was found that the staying on rate was higher particularly for students of Asian origin because of their high educational aspirations and the belief that without a good education their chances of success were limited (Marks et al 2000, Steinberg, Dornbusch \& Brown 1992, Sturman 1985). However US studies reveal disparities in educational achievement among racial and ethnic groups, for example the poor educational outcomes of African-Americans and Mexican-Americans. It is argued that cultural differences in values, attitudes and behaviours help explain why some racial and ethnic minorities in America are successful in school while others are not (Ogbu 1992).

\section{Indigenous status}

Indigenous Australian youth are most disadvantaged in relation to school completion and in relation to progression to higher education. In 1998 the apparent national retention rate for indigenous Australians was $32.1 \%$, less than half the rate $(72.7 \%)$ achieved by other Australians. Indigenous males were found to have poorer retention and participation rates compared to indigenous females (Lamb et al 2004, McMillan \& Marks 2003). High rates of absenteeism and truancy not only had an adverse effect on academic achievement but also resulted in a sense of non-belonging at school causing these students to become social outsiders. This was found to correlate with an increase in juvenile crime (House of Representatives Standing Committee on Education and Training's Report on Truancy and Exclusion from School 1996, Gardiner 1996, Rothman 2002).

The prospect of future employment was found to be a major determinant in student attitude to schooling. In a national survey of indigenous and non-indigenous students $40 \%$ of non-indigenous students were concerned about employer attitudes. In contrast, $60 \%$ of indigenous students felt that employer attitudes would act as a barrier to their aspirations (Craven, Tucker, Munns, Hinkley, Marsh \& Simpson 2003). Thus for indigenous parents and students, schooling, in theory, is valuable for good 
employment but since good jobs seemed almost unattainable, schooling itself was devalued and their educational aspirations blighted (Craven et al 2003, McInerney 1991).

\section{Academic achievement and motivation}

Poor academic achievement as a powerful predictor of non-completion of schooling is well established in the international literature. In the US, predictions of drop out rates were made using failing grades as a criterion (Barrington \& Hendricks 1989). Similarly, Canadian studies also found that school achievement was a better predictor of early leaving than socio-economic variables (Janosz, LeBlanc, Boulerice \& Tremblay 1997).

Furthermore, research in Australia and the US confirmed that academic achievement as a strong predictor of school completion also played a long-term role in the drop out process. Young people who struggle with schoolwork in the early years experience a sense of frustration and failure accompanied by a decline in motivation and self-esteem (Ainley 1993, Astone \& McLanahan 1991, Finn 1989, Kaplan, Peck \& Kaplan 1997). When they commence studies in Senior School they experience a sense of powerlessness as they grapple with theoretical concepts and the demands of time management, organisation and schoolwork requirements which overwhelm many who finally make the break from school (Alexander, Entwisle \& Olsen 2001, Lloyd 1978, Teese \& Polesel 2003, Williams, Long, Carpenter \& Hayden 1993).

\section{Work-related factors}

Work and income-related reasons have been identified as key reasons for noncompletion. From the survey on education and training experience in Australia, ABS (2000) reported that $46 \%$ of non-completers left because they wanted to get a job and earn money. Getting an apprenticeship was also a major reason nominated by $42.5 \%$ of students (Lamb et al 2004).

Findings from large surveys conducted in the United Kingdom also indicate that the desire to get a job and earn an income were major reasons for non-completion (Kysel, West \& Scott 1992, Maychell \&Evans 1998, Vaarlam \& Shaw 1984). Thus for the majority of non-completers the pull of work constitutes a central factor in the decision to leave school early (Lamb et al 2004, McMillan \& Marks 2003). Of significance in the Australian context is the finding that some young people, despite the concern about employment prospects, do not believe that staying on at school would enable them to gain successful entry into the labour market (Craven et al 2003, Lamb, Dwyer \& Wyn 2000, Pitman \& Herschel 2002, Smyth, Hattam, Cannon, Edwards, Wilson \& Wurst 2000, Teese 2002). 


\section{School-related factors}

Findings from quantitative and qualitative studies indicate that school related factors play a significant role in early school leaving. Dwyer (1996) observes:

Early leaving is often more related to the push from a negative experience of school than the pull of a job or a clear idea of future pathways to adulthood ... Most of the young people's reasons had to do with wanting to get away from school, especially because the teacher/student relationship was a profoundly negative experience or they found the school environment and work uninteresting and uninspiring (p.15).

Lamb, Dwyer \& Wyn (2000) found that up to $15 \%$ of non-completers left in order to do training or study not available at their school. Curriculum and teaching and learning practice that is directed towards preparing students for entry into university greatly undermine the promise of equal opportunity. This was found to alienate a number of young people who considered it irrelevant to their needs and interests (Ball, Maguire \& Macrae 2000, Dwyer 1996, Te Riele 2000). Those individuals who attempted to contest the boundaries and confront the barriers encountered social control that manifested itself through well-articulated views about what was 'deviant', 'out of place' or likely to threaten the 'image' of the school (Smyth \& Hattam 2004, p. 10). The negative impact of school culture on the lives of some young people is consistent in many qualitative studies on non-completion (Brown et al 2001, Henry \& Roseth 1985, Holden \& Dwyer 1992, MacDonald 1999, Smyth, Hattam, Cannon, Edwards, Wilson \& Wurst 2000). Although these qualitative findings are based on small samples they provide many additional and important reasons for noncompletion of a more select group of non-completers (McMillan \& Marks 2003).

Evidence from the vast body of research on the issue of non-completion suggests that the complexity and uncertainty that characterise young people's lives cannot be accounted for in a normative model of youth transition. The argument being made in this paper is that educational policy and practice should allow for the de-standardised, fractured and protracted nature of youth transitions. This often involves a number of critical turning points. The re-entry into second chance education is one of them (Bloomer \& Hodkinson 2000, Raffo \& Reeves 2000, Wyn et al 2004, Wyn \& White 1997). The case for second chance education is developed through the ensuing exploration of pertinent theoretical positions surrounding the development of youth identities. 


\section{Understanding agency within the context of risk society}

It is a well-established fact that young people today are growing up in a different world to that experienced by previous generations. With the onset of late modernity (Beck 1992, Giddens 1991) society has acquired more science, technology and knowledge. But as knowledge is continually changing or being challenged, there is less certainty and growing insecurity (Giddens 1991). In the 'risk society' (Beck 1992) young people today are confronted by risks of a global nature, stemming from the threat of nuclear war, environmental disasters, the restructuring of the labour market and the weakening of traditional links between the family, school and work. Young people are now forced to negotiate a new set of hazards, which impinge on all aspects of their day-to-day lives. Self-identity becomes fragile and subject to constant reinterpretation (Giddens 1991). This constant reinterpretation and construction of personal biographies in the light of changing experiences is described as a 'reflexive project' (Giddens 1991).

Within the risk culture, 'no aspects of our activities follow a pre-ordained course, and all are open to contingent happenings' (Giddens 1991, p. 28). Thus, the rhetoric of structured pathways through education is tested by the persistent and substantial proportions of non-completers who leave school early (Lamb et al 2000). These theorisations of the discontinuities and changes in young people's lives may be juxtaposed with those that emphasise the continuity of traditional inequalities related to socio-economic status, gender and ethnicity. It is argued that despite the globalised nature of risks and social cleavages in late modernity, deep-seated social and structural influences remain, though they are often experienced and addressed individually (Furlong \& Cartmel 1997).

Recent research undertaken in the United Kingdom, Germany and Australia has highlighted the need for a re-consideration of the influence of structural factors. There is acknowledgement of the significant impact of social structures on the life experiences and life chances of young people. However the influences of social structures are not considered to be deterministic (Ball et al 2000, Bynner \& Roberts 1991, Evans 2002, Evans \& Heinz 1994, Green, Mitchell \& Bunton 2000, Rudd \& Evans 1998). Rudd \& Evans (1998) argue that young people's experiences of life were complicated by the fact that they can respond to structural influences and make their own minor and major decisions about life experiences. This gave rise to the relatively new development of the concept of 'agency', which sees young people as having a past and imagined future possibilities both of which guide and shape actions in the present (Evans 2002, Emirbayer \& Mische 1998). This sense of agency and taking control of one's life is played out during the re-entry process when young people actively seek a second chance at education. 
... many in the younger generation are becoming increasingly proactive in the face of risk and uncertainty of outcomes, and are making pragmatic choices for themselves which enable them to maintain their aspirations despite the persistence of structural influences on their lives (Wyn \& Dwyer 1999, p. 5).

This is corroborated by findings from a recent qualitative study (Wyn et al 2004), which indicates that $15 \%$ of young people, who left school to take up jobs and start a career, soon discovered that the jobs were not ongoing for a number of reasons. Through critical reflection on their precarious situation they made the constructive decision to return to education. Thus, young people are seen to be actively managing and recreating their personal and educational biographies (Evans 2002).

\section{Exploring the frameworks of youth transitions}

The complexity and unpredictability of the life experiences and future prospects of young people points to a need to re-examine established understandings of youth transitions and frameworks which have been adopted in youth research and educational policy in the past (Wyn \& Dwyer 1999). It is argued that the changes are significant enough to merit a re-conceptualisation of youth transitions (Furlong \& Cartmel 1997).

Transition is central to the lives of young people and metaphors are the prime means through which the mobility of young people has been captured. The different phases in the development of policy and research on youth transitions are often defined through the metaphors that were predominant during each phase (Evans \& Furlong 1997).

$1960 s$ the metaphor of filling society's 'niches' reflected the emphasis on successful integration into adult roles.

1970 s the emergence of the 'pathways' metaphor captured changes in the youth transition process, which was now perceived to be longer and more complex as a result of an increase in education participation due to a decline in youth employment.

1980 s the term 'trajectory' indicated that social forces (not government designed pathways) were a powerful influence in determining the availability of resources to the young person and the momentum of the transition itself.

1990s the metaphor of 'navigations' suggested that through the exercise of personal agency individuals tried to actively shape their lives within the opportunities and constraints that they encountered. 
The two predominant metaphors discussed in the ensuing section juxtapose policy makers' conceptions of transitions with the recent theoretical positions advanced by sociological thinkers. The first of these is the pathways metaphor that pervades education and training discourse in Australia. Its strong suggestion of linear transitions has contributed to a number of misleading assumptions (Dwyer \& Wyn 1998, Cohen \& Ainley 2000, EGRIS 2001, Evans \& Furlong 1997, Smyth \& Hattam 2004, Wyn \& Dwyer 2000, Wyn \& White 1997).

1. A young person's transition is solely the school-to-work passage. This narrow focus ignores other transitions such as family, household or life style transitions and does not appear to include the equally important reversible movement of re-entry into education.

2. All transitions are in the same directions. This often refers to institutionalised processes such as particular courses in education and training well trodden by the mainstream of young people. This perception ignores the 'yo-yo' movements (EGRIS 2001, p. 104) and reversible transitions that characterise the dynamic of youth life.

3. The pathways are visible and clearly accessible so if some young people do not make it to the destination the fault lies with them. This view ignores the potent influence of varied factors (previously discussed) that may impede transition and assumes that 'destination' is a fixed state, consistent across all groups.

4. The pathway outcomes are predictable and equitable. Such a view fails to take into account the changing structure of the labour market and the fact that access is quite often dependent on social class, gender, sexuality and race.

The second metaphor is a reflection of more recent perceptions of youth transitions as processes marked by a series of arrivals and departures. This movement is captured through circular or spiral imagery (Evans 2002, Munns \& McFadden 2000, Smyth \& Hattam 2004, Wyn \& White 1997). Wyn and White (1997) refer to this movement in their description of the 'boomerang children' (p. 96) for whom leaving education and returning is an ongoing process.

This theme is developed further through the metaphor 'navigating a transition' to describe the self-determination and sense of personal agency evident in the choices made by young people (Smyth \& Hattam 2004, p. 37). There is the critical moment when they decide to leave school and the equally decisive stage during which they strive to re-connect with learning through second chance education. Interview material (Smyth \& Hattam 2004) and case studies (Ferber 1999, Munns \& McFadden 2000, Wyn et al 2004) on re-entry into education and training support the claim that young people are capable of creatively manipulating structural and individual factors, 
of making assessments of risk and need, and of creating opportunity structures for themselves (Ball et all 2000, Evans 2002, Smyth \& Hattam 2004, Wyn \& Dwyer 1999, Wyn et al 2004, Wyn \& White 1997).

Recent research suggests that the support systems available to young people prior to early departure, at the point of early departure, after departure, at the re-entry stage and during the period of second chance education are limited, ad hoc and fragmented. The complexity of youth transitions is an area that has not been addressed adequately by current educational policy (McIntyre \& Melville 2000, Smyth \& Hattam 2004, Wyn et al 2004, Wyn \& White 1997). A major challenge for educational and youth research on transitions is overcoming the difficulty in systematically documenting data on other important dimensions of young people's lives, apart from education and employment data, of which the latter is readily available. Wyn and Dwyer observe:

The old linear categories which define 'transition' almost exclusively in terms of the two dimensions of 'study' and 'work' continue to dominate the parameters of most of the large-scale statistical data bases. Evidence about other priorities which young people themselves may have personal lifestyles, leisure interests and even family priorities - tends to be piecemeal, sporadic or market-driven (2000, p. 153).

It is these findings that can help shape policy response to the issue of non-completion and to a re-consideration of the relevance of second chance education by providing valuable insights into the ways in which young people struggle to re-construct and define their identities as they re-engage with learning.

A case can be made that educational pathways should allow for reversible movements to accommodate the complex transition processes of young people struggling to comprehend the existential issues of late modernity and the uncertainties of our risk society (Beck 1992, Giddens 1991, Smyth \& Hattam 2004, Wyn \& White1997). In this context second chance education programs that facilitate a re-engagement with learning could enable disaffected students to create or regain successful selves and identities (Smyth \& Hattam 2004, Wyn et al 2004, Wyn \& White 1997).

\section{The concept of second-chance education}

Second chance education is based on the idea that 'through an organised structure an individual can actualise an educational opportunity missed or failed the first time around' (Shavit, Ayalon \& Kurleander 2001, p. 2). The philosophy underpinning second chance education is that "errors made by the selection mechanisms of the 
educational system or by individuals who terminated their own educational career could be corrected at a later stage' (Yogev 1997, p. 469). Thus, students who do not succeed on the main road are given another chance to do so, not via a parallel road, but rather a re-entry portal into the main track (Shavit et al 2001).

There are three basic criteria by which second chance frameworks provide a genuine 'second chance' (Inbar \& Sever 1989).

1. Accessibility - second chance systems should be non-selective

2. Effectiveness - second chance systems should improve educational attainment

3. Equivalence - second chance programs should lead to similar if not the same rewards for success as the first chance provides

In the Australian context, findings from a small body of literature suggest a shift from the linear view of retention to Year 12 to a consideration of re-entry into education through second-chance education programs outside the school system (Dawe 2004, Leong 2002, Spierings 2003, Smyth \& Hattam 2004, Te Riele 2000, Wyn et al 2004).

Some groups of young people decide to leave school early because it ceases to be a viable option. However, the decision to leave school early does not constitute a closed or completed episode. The first chance is not necessarily the last chance and mobility may be achieved through non-traditional routes (Inbar \& Sever 1989, Munns \& McFadden 2000, Wyn et al 2004). For many young non-completers whose experience of the first chance was one of marginalisation, disengagement and alienation, aspiring for a second chance signifies their struggle to reconstruct their educational identities and experience a sense of self-worth. Munns and McFadden conclude:

They want a solid base from which to build a more satisfying and productive life. They want to reconnect with education as a socially supportive institution and to ameliorate their sense of personal and cultural fracture. They want to prove to themselves and others that they can 'do it', i.e. return to education and succeed (2000, p. 71).

Thus for many young people the notion of a 'second chance' is linked with the desire to change the circumstances of their lives by returning to education after episodes of educational failure, homelessness, emotional deprivation, criminal behaviour or even sickness (Munns \& McFadden 2000). 


\section{The compensatory role of second chance education: The building of social capital}

Studies of second chance education programs in TAFE and ACE settings in Australia suggest that the real value of these programs is to be found in the intangible benefits that students derived from them (Saunders, Jones, Bowman, Loveder \& Brooks 2003, Wyn et al 2004). These related to the personal satisfaction experienced by students through the development of social skills, a sense of greater control over their lives, the confidence to seek out new opportunities, make well informed choices and pass on these benefits through interaction with family members and communities. Of significance were the meaningful relationships that were formed with peers and staff and the sense of belonging to a group.

Bourdieu (1986) in his definition of social capital refers to the actual or potential resources, which are linked to the possession of a durable network of relationships or to membership in a group. For Coleman, the strength of ties within the group is an important aspect of social capital.

Social capital, however, comes about through changes in the relations among persons that facilitate action. If physical capital is wholly tangible, being embodied in observable material form, and human capital is less tangible, being embodied in the skills and knowledge acquired by an individual, social capital is less tangible yet, for it exists in the relations among persons. Just as physical capital and human capital facilitate productive activity, social capital does as well. For example, a group within which there is extensive trustworthiness and extensive trust is able to accomplish much more that a comparable group without that trustworthiness and trust (1988, pp. 100-101).

The qualitative benefits experienced through re-engagement with learning are confirmed by studies conducted in the United Kingdom. The National Institute of Adult Continuing Education (NIACE) 1999 survey findings reported that 87\% of respondents experienced improvement in their physical health, as a result of participation in learning, while $89 \%$ reported positive emotional or mental health benefits (Aldridge \& Lavendar 2000). This is supported by findings from the Dench \& Regan (2000) study, which concluded that a high proportion of people benefited from learning in terms of general well being. In addition to increased confidence and selfesteem some of the greatest general benefits highlighted were the development of new friends, contact with other people and improved relationships with other people.

In this context it is worth introducing Walker's (1987) theory of intercultural articulation for a different perspective on the way individuals may add to their social 
capital. There is not scope within this article to explore this in detail, however the benefits gained through the implementation of intercultural articulation are highlighted.

The dualistic view of the productive capacity and reproductive nature of education is particularly relevant to second chance education. The findings of an ethnographic inquiry into the effects of a second chance program in Sydney highlight how pedagogic practices offer the potential for groups to access advantage or close off such opportunities and unintentionally create the conditions for recycling disadvantage (McFadden 1996). However the negative effects may be minimised through the implementation of intercultural articulation (Walker 1987). This refers to a teaching paradigm that allows for positive and democratic teacher/student, student/student relations. This is achieved through cultural convergence, 'an understanding and affinity' for the cultural groups involved in the educational program rather than cultural divergence (Walker 1995, p. 41).

While cultural divergence forces learners to opt for solutions to their problems exclusively from within the resources of their own cultural group, cultural convergence encourages them to see other options and possibilities for action from the repertoires and reservoirs of other cultural groups. Findings from the ethnographic study of a bridging programme in Sydney in 1992 and 1993 (McFadden 1996) and from interviews with students enrolled in re-entry programs in New South Wales, Victoria and South Australia (Wyn et al 2004) highlight the positive effects of intercultural articulation. Both studies report the new possibilities and options for action that became available to learners through intercultural articulation with other groups of learners in the class and with teaching staff. Through these networks of social relations students were no longer trapped in the confines of their own culture but were able to enrich their social capital by drawing on the collective resources of the group.

Counter-hegemonic pedagogic strategies were also instrumental in promoting a culturally convergent experience. Wyn et al (2004) report that group-devised work that involved learning to work with others, being part of a group and developing skills in teamwork, negotiation and conflict resolution provided plenty of social capital and hence opportunities for individual change and development.

As previously noted, the profile analysis of non-completers seeking re-entry into education revealed a significant deficit in social capital, attributed to factors such as low SES, family structure, gender, indigenous status and poor academic achievement. This is supported by the literature on re-entry into second chance education, which highlights the disadvantage experienced by this cohort of young people. The findings 
from the literature draw attention to the compensatory but crucial role of second chance education in enabling these learners to move beyond their past experience of educational failure and reclaim successful individual identities (Dawe 2004, Ferber 1999, McFadden 1996, Smyth \& Hattam 2004, Wyn et al 2004).

\section{Re-entry into education through TAFE: Reclaiming the social service view}

While it is acknowledged that re-entry portals are available at second chance education colleges and in ACE settings, a discussion of these models is beyond the scope of this paper. The focus here is on exploring TAFE as an example of one provider of second chance education. Re-entry into education through TAFE is considered in view of the traditional role that TAFE has performed in providing for and supporting the access and participation of disadvantaged groups (Powles \& Anderson 1996). From this perspective, a review of the role of TAFE is relevant in the light of the dramatic changes undergone by the institution in recent years and the impact of these changes on the second chance role that TAFE was historically designed to support.

\section{Dichotomy in TAFE: Social service versus economic utility}

In the early years of its development Australian technical and further education was orientated towards the working class and had dual goals; to provide skills instruction for the workforce and to offer people from lower socio-economic backgrounds opportunities for personal development and advancement (Murray-Smith 1966, 1971, Powles \& Anderson 1996). The social service view was also reflected in the central vision of the Kangan Report (1974) wherein TAFE was not to be mainly 'the supplier who meets the client needs for skilled labour, but as supplying each person with education to meet his freely-chosen vocational need within the context of the vocational world' (p. 11).

The social service view of TAFE relates back to the series of psycho-social and structural barriers to post-compulsory education participation in school identified by the Kangan Committee (Kangan 1974, p. 11).

- Fear of failure (relating to school experiences)

- Fear of tests and examinations (resulting in the public exposure of failure)

- Rigidly defined course requisites

- Inflexible learning methods

- Hierarchical structures in favour of high academic achievers 
The Committee believed that TAFE was in the best position to address the barriers faced by disadvantaged groups. Thus from the mid 1970s a range of access programs were developed premised on TAFE's role in redressing social imbalances (Powles \& Anderson 1996)

The 1980s saw large numbers of young people enrolling in TAFE transition education programs and pre-employment programs (Powles \& Anderson 1996). Yet simultaneously, many participation and equity programs that aimed at increasing equity of access to mainstream courses were discontinued because they were nonaccredited, ad hoc and not properly integrated with mainstream courses. Furthermore, they were considered marginal to mainstream, and hence underfunded and under-resourced (Anderson 1985, Lechte 1985, Noonan 1985, Sweet 1985). The technically oriented workshop culture of TAFE colleges also presented a strong barrier to the acceptance of special access and equity programs (Kell 1990).

By 1990, the notion of economic utility had gained ascendance in TAFE. In the Scott Review (1990) of the TAFE system in NSW the quasi welfare role of TAFE was subsumed in an industry-driven, market-tied, workplace orientated vision of TAFE (Broadbent 2001, Schofield 2001). In this context, the human capital paradigm is dramatically altered. With students now cast as consumers, education and training is defined in terms of a commercial transaction rather than a process of social and cultural formation. The focus is on skills formation, with the principal objective to increase productivity and competitiveness of industry rather than contribute to social and personal development. Industry, rather than the individual student is now viewed as TAFE's principal client (Boomer 1987, Marginson 1993, Powles \& Anderson 1996).

In current, key policy documents such as Shaping our future: Australia's national strategy for vocational education and training $2004-2010$ industry is identified as the key player in vocational education and training.

- Industry leads key aspects of vocational education and training (VET)

- Industry defines the skills that people need to work

- Industry advises about the products and services it requires

- Industry promotes how businesses and employees can undertake VET both in and outside work and the ensuing benefits

The role of Registered Training Organisations (that include TAFE colleges) is to translate the needs of industry into client-focussed, quality training programs. While inclusivity and equity are incorporated into the national strategy, scepticism about 
the priority of these issues has been expressed on earlier occasions. Powles \& Anderson (1996) express this notion in the following way:

In extremis, provision for disadvantaged groups becomes one of many institutional performance indicators, given lip service by government and unsupported by the public purse (p. 3).

Despite a marked decline of the social service view of TAFE since the 1990s and the challenges that TAFE confronts in continuing to offer access programs, recent studies suggest that 'enabling courses' in TAFE colleges are often the preferred choice for young people seeking to reconnect with learning (Bagshaw \& Brown 2001, Broadbent 2001, Dawe 2004, Ferber 1999, Leong 2002, Phan \& Ball 2001, Powles \& Anderson 1996, Te Riele 2000, Wyn et al 2004). The term 'enabling courses' is used to describe a range of pre-vocational courses, bridging courses, literacy and numeracy programs, job seeker preparation and employment skills development programs and life skills programs aimed at various target equity groups (Phan \& Ball 2001). Students who complete these courses generally attain a recognised qualification, an AQF Certificate I, II or III (Australian Qualification Framework).

A comparison between the 1998 figures of the Phan and Ball (2001) study and the 2001 figures presented by Dawe (2004) validate the claim of a substantial increase in the number of 15 to 19 year olds enrolled in enabling courses mostly at TAFE institutes.

\begin{tabular}{lccc}
\hline Age group & $\begin{array}{c}\text { Total number of VET } \\
\text { students ('000) }\end{array}$ & $\begin{array}{c}\text { Number of enabling } \\
\text { course students ('000) }\end{array}$ & $\begin{array}{c}\text { Proportion of students } \\
\text { in enabling course (\%) }\end{array}$ \\
\hline $15-19$ years & 306.4 & 18.6 & 6.1 \\
\hline $20-24$ years & 242.6 & 10.7 & 4.4 \\
\hline $25-29$ years & 180.4 & 9.8 & 5.4 \\
\hline $30-39$ years & 310.8 & 19.1 & 6.2 \\
\hline $40-49$ years & 238.0 & 13.7 & 5.7 \\
\hline $50-59$ years & 108.7 & 5.7 & 5.3 \\
\hline $60-64$ years & 18.8 & 1.3 & 7.0 \\
\hline
\end{tabular}

Source: Adapted from Phan \& Ball (2001, p. 15)

Table I

Proportion of Students in Enabling Courses in Australia, 1998 
Of the seven age groups depicted in Table 1, one of the highest proportion of students (6.1\%) undertaking an enabling course belonged to the 15 - 19 years category. Table II shows an increase in numbers of 15 to 19 year olds enrolled in enabling courses, over a three-year period. In 2001, the proportion of 15 to 19 year olds who were engaged in an enabling course had risen from $6.1 \%$ to $8.0 \%$. This age group were now the most represented in enabling courses.

\begin{tabular}{lccc}
\hline Age group & $\begin{array}{c}\text { Total number of VET } \\
\text { students ('000) }\end{array}$ & $\begin{array}{c}\text { Number of enabling } \\
\text { course students ('000) }\end{array}$ & $\begin{array}{c}\text { Proportion of students } \\
\text { in enabling course (\%) }\end{array}$ \\
\hline $15-19$ years & 416.0 & 33.2 & 8.0 \\
\hline $20-24$ years & 266.6 & 13.6 & 5.1 \\
\hline $25-29$ years & 185.8 & 10.2 & 5.5 \\
\hline $30-39$ years & 329.5 & 19.8 & 6.0 \\
\hline $40-49$ years & 276.8 & 15.8 & 5.7 \\
\hline $50-59$ years & 148.1 & 7.5 & 5.1 \\
\hline $60-64$ years & 27.4 & 1.7 & 6.3 \\
\hline \multicolumn{5}{c}{ Source: National Centre for Vocational Education Research 2001 National VET Collection } \\
\multicolumn{4}{c}{ Adapted from Dawe (2004, p. 19) } \\
Table II \\
Proportion of Students in Enabling Courses in Australia, 2001
\end{tabular}

Findings from the Phan and Ball (2001) study and Dawe's (2004) study highlight a significant trend in student enrolments in enabling courses from the15 to 19 year old age group. During 1998 those students who had left school before completing Year 10 and were unemployed were three times more likely to undertake study in an enabling course when compared to their counterparts. In 2001, students who had left school before completing Year 10 and who were unemployed were four times more likely to undertake enabling courses than their counterparts (Dawe 2004).

Low socio-economic status, indigenous background, disenchantment with the school system and the perception of the TAFE environment as being a more attractive alternative to school have been cited as key factors contributing to this trend (Dawe 2004). However, a more extensive examination of the factors that influence re-entry into education through TAFE is warranted.

\section{Profile of students seeking re-entry into education through TAFE}

Findings from the NCVER 2001 National VET Collection indicate that 27\% of females and $38.6 \%$ of males in the 15 to 19 year old age group undertook an enabling course (Dawe 2004), a marked increase from the $18.7 \%$ and 29.4\% in 1998 (Phan \& Ball 
2001). Enabling course students who identified as being of Aboriginal and Torres Strait Islander descent were $37.7 \%$. Of significance is the $40.6 \%$ of 15 to 19 year olds from rural and remote regions undertaking an enabling course (Dawe 2004). Often there is nowhere else for them to go and TAFE may be the only second chance opportunity available to them (Dawe 2004, Wyn et al 2004).

\section{Factors that influence re-entry into enabling courses at TAFE}

Low SES, a major determinant for non-completion is also found to be a strong factor influencing re-entry into enabling courses. It has been argued that choosing the TAFE alternative 'is rooted in the complex of values, orientations, attitudes and behaviours that characterise families in different social status groups' (Williams 1987, p. 112). Students from low SES groups were found to be concentrated in preparatory and basic skills courses (King 1987, Powles \& Anderson 1996, Williams 1987). The high material costs for mainstream VET courses were also found to be a significant barrier to entry (King 1987). In this context the Youth Allowance has been cited as an incentive to enrol in enabling courses though the trend of younger people accessing these programs was established before its introduction. Nevertheless there is some indication that it is reinforcing this trend (Ferber 1999).

The quality of staff - student relationships is a significant facilitator. The positive attitude of staff towards students at the time of re-entry and the informal nature of the pre-enrolment interview are found to alleviate the stress experienced by many young people who are attempting to re-connect with learning after earlier experiences of failure and exclusion. Of importance were the encouraging and affirmative teacher attitudes towards students throughout the duration of the course (Ferber 1999, Smyth \& Hattam 2004, Wyn et al 2004).

Ease of access and clear pathways were also found to encourage re-entry. Findings from recent studies indicate that enabling programs play a significant role in helping young people complete their general education, build basic study skills and gain confidence. Often within a program there is the opportunity for students to proceed from Certificate I up to Certificate III or IV. Links with other programs offer students the chance to choose a preferred pathway (Dawe 2004, Phan \& Ball 2001, Wyn et al 2004). There is also evidence that achievement in general education courses is now recognised as a minimum requirement of entry into mainstream VET courses and some areas and levels of employment including the public sector and the defence forces (Bagshaw \& Brown 2001).

The influence of student-centred approaches to learning as a significant determinant for re-entry cannot be overstated. Flexible learning and assessment strategies, flexible learning spaces, manageable sized modules, group devised work, a culture of 
support, the application of adult learning principles and customised learning programs were found to enhance student re-engagement with learning. Other important components of the learning paradigm were the establishment of clear boundaries and expectations and connections with broader community support networks (Smyth \& Hattam 2004, Wyn et al 2004).

\section{Youth transitions and outcomes after completing an enabling course}

It is difficult to establish equivalence between enabling programs and Year 12 qualifications. Enabling programs may not adequately address all the criteria that apply to second chance frameworks (Ball \& Lamb 2001). Nevertheless, the literature suggests that these TAFE programs have enabled some students to effectively reengage with learning and make successful transitions into further education and/or employment (Dawe 2004, Phan and Ball 2001, Smyth \& Hattam 2004, Wyn et al 2004). This is confirmed by findings from the national VET data collection. Table III shows the level of qualification undertaken by students after completing an enabling course.

\begin{tabular}{|c|c|c|c|c|c|}
\hline Age & \multicolumn{5}{|c|}{ Level of Qualification } \\
& Higher & Same & Lower & \multicolumn{1}{c|}{ Other } & \multicolumn{1}{c|}{ Total } \\
\hline 15 - 19 years & 41.6 & 42.7 & 5.7 & 10.1 & 100.0 \\
\hline 20 - 24 years & 40.7 & 44.0 & 5.7 & 9.7 & 100.0 \\
\hline $25-29$ years & 32.7 & 49.6 & 6.7 & 11.0 & 100.0 \\
\hline $30-39$ years & 30.6 & 47.8 & 7.4 & 14.3 & 100.0 \\
\hline
\end{tabular}

Source: Adapted from Phan \& Ball (2001, p. 24)

\section{Table III}

\section{Level of Qualification Undertaken by Students after Completing an Enabling Course}

Of the four age groups presented in Table III, nearly 42\% of those aged 15 to 19 years made a successful transition to a higher-level qualification. While the percentage of early school leavers that belonged to this group is not known, it may be assumed that given the age range, a considerable number may have been non-completers. The point to be noted is that these young people had benefited from a second chance education program in a setting outside the school system and gained the confidence, knowledge and skills to undertake further learning.

In the Australian context, the completion of an enabling course does not guarantee a student a job, however it does not mean that enabling courses were not effective in assisting individuals to gain employment (Phan \& Ball 2001). 


\begin{tabular}{|c|c|c|c|c|c|c|}
\hline \multirow{2}{*}{ Age group } & \multicolumn{3}{|c|}{ Before commencing enabling course } & \multicolumn{2}{c|}{ After enabling course completion } \\
\cline { 2 - 7 } & Employed & Unemployed & $\begin{array}{c}\text { Not in } \\
\text { labour force }\end{array}$ & Employed & Unemployed & $\begin{array}{c}\text { Not in } \\
\text { labour force }\end{array}$ \\
\hline $15-19$ & 24.6 & 35.3 & 39.1 & 34.7 & 35.9 & 26.7 \\
\hline $20-24$ & 26.1 & 46.2 & 27.4 & 32.3 & 35.6 & 30.4 \\
\hline $25-29$ & 29.3 & 40.5 & 29.6 & 32.1 & 32.6 & 34.0 \\
\hline $30-39$ & 26.9 & 30.6 & 41.9 & 28.5 & 30.1 & \\
\hline \multicolumn{7}{|c|}{ Source: Adapted from Phan \& Ball (2001, p. 35). } \\
Employment Status Prior to and after Enabling Course \\
Completion in Australia
\end{tabular}

The national VET data presented in Table IV indicate that the highest percentage of employment after completion of an enabling course is recorded for the 15 to 19 year old age group (Phan \& Ball 2001, p. 35). It may be inferred that second chance education programs in TAFE settings could enable young people to negotiate successful transitions and also equip them with the skills required for the workplace.

The qualitative benefits derived by students cannot be ignored. Increased selfconfidence (as a result of knowledge and skills development), improved lifestyle, increased networks for support, development of social contacts and a sense of belonging have been cited as significant outcomes derived from participation in enabling programs and major contributors to student well being (Leong 2002, Ferber 1999, Phan \& Ball 2001, Te Riele 2000, Wyn et al 2004).

However, caution must be taken against the view that these TAFE programs are the panacea for all disaffiliated youth. The risk of students being trapped in an 'enabling course roundabout' and not progressing on to higher-level courses or employment has been debated (Wyn et al 2004, p. 14). Similarly, the possibility that these programs could sometimes result in 'recycling disadvantage' has also been mooted (McFadden 1996, p. 87).

\section{The gaps in educational policy and practice in Australia}

Policy formulation in Australia, for the most part, continues to be driven by a view of retention that emphasises linear progression pathways. At the national level the Prime Minister's Youth Pathways Action Plan Taskforce (2001) emphasises the importance of retaining young people through the development of more effective postcompulsory education and training that would facilitate their transition into 
employment. At the state level, initiatives like the amalgamation of the education and training sectors, in Western Australia, into the Department of Education and Training, was undertaken with the purpose of achieving an integrated approach to the education and training of $15-17$ year olds that focuses clearly on increasing retention' (Western Australian Department of Education and Training 2003, p. 3). Emerging legislation to raise the school leaving age in Western Australia and Queensland is also aimed at increasing the retention rate of 15 to 19 year olds in full time education and training (Carpenter 2004).

Continued emphasis on the compulsory school leaving age has been described as an anachronism from the Fordist era (Spierings 2002). Similarly, the developmental model, which age-based schooling reflects, is seen to be increasingly out of touch with the reality of young lives (Wyn \& Dwyer 2000). The immense challenge posed by the complex life patterns and transitions of young people is universally acknowledged. What is required is a concerted effort by policy makers and practitioners in re-orientating educational policy and practice from simply managing these complexities and uncertainties to embracing it and encouraging discourse about it (Smyth \& Hattam 2004, Spierings 2002, Wyn \& Dwyer 2000, Wyn \& White 1997).

The presumptions of policy makers about the mobility of young people are also called into question. The minimalist and deterministic nature of the propulsion model' (Rudd \& Evans 1998, p. 60) of the current education system in Australia is based on one such assumption that all young people may be propelled through the education system in quest of a credential and as a result obtain employment and contribute usefully to the economy (Rudd \& Evans 1998, Smyth \& Hattam 2004). Such a view refuses to recognise a salient feature of 'late modernity', which is the shift from predictable biographies to the more individualised biographies of young people in the current 'risk society' (Beck 1992, Giddens 1991). Thus multiple forms of transition that may include re-entry into second chance education and the part young people themselves play in shaping their futures are seriously undermined (Rudd \& Evans 1998, Smyth \& Hattam 2004, Te Riele 2000, Wyn \& Dwyer 2000, Wyn \& White 1997).

The power relations inherent in educational policy and practice masked by a false humanitarianism further alienate young people (Freire 1970). Official policy constructions continue to position young people as passive subjects or 'consumer recipients and not as active co-participants involved in shaping their life conditions' (Fraser 1989, p. 155). By refusing to think 'against the grain' (Roman 1996, p. 2) policy makers have excluded those young people who 'refuse to be institutionalised' (Fine 1996, p. xiv). Young people's decisions to re-engage with learning are subsumed under 'monological deficit assumptions' (Roman 1996, p. 3) that stigmatise those who resist the 'social magic' (Fine 1996, p. xiv) of school. Educational policy responses are 
thus seen to have contributed to the alienation of early school leavers through a lack of clear pathways back into education and training, very little provision for structured re-entry and limited opportunities for gaining access to second chance education (Vinson 2001, Smyth \& Hattam 2004, Spierings 2002, Wyn et al 2004).

The lack of an effective tracking mechanism for early school leavers in Australia is another issue that has not been adequately addressed by policy. This is in contrast to some European models where 'schools have a statutory responsibility to track their early leavers and monitor their experiences' (McIntyre \& Melville 2000, p. 9). In addition, the lack of a structured approach to the provision of information and support to early school leavers and those seeking re-entry is another issue that needs to replace the ad hoc arrangements through CentreLink and the random referrals of a youth worker (McIntyre \& Melville 2000, Wyn et al 2004).

Findings from the Central Coast study indicate that school responses to early school leavers are for the most part reactive rather than proactive. Young people who made trouble were in some instances presented with a folder of information about local jobs and courses. In many cases the suddenness of departure made school intervention difficult. In other instances those who left under a cloud were least likely to receive a sympathetic farewell or relevant information of which they had the greatest need. Few early leavers received an exit interview or were provided with a letter of reference (McIntyre \& Melville 2000, p. 9).

The issue of re-entry also requires the attention of policy makers and practitioners. While the sustainability of the comprehensive one school model has been called into question (Spierings 2003, p. 14), alternative institutions, which provide students with a second chance to complete their secondary education or equivalent, are not widespread in Australia. Second chance colleges are few and far between and usually located in metropolitan areas. Second chance options in regional areas are limited to TAFE or ACE providers and practically absent in remote rural locations. Continuity of many ACE programs is dependent on funding and numbers are limited. TAFE is often the only option left for those seeking re-entry into education. Even here significant structural constraints pose barriers to re-entry. Age limitations, entry requirements, upfront fees and lack of formalised links with schools act as major impediments (Wyn et al 2004). In addition, there is the fragmentation of support services and young people having to often rely on the goodwill of individuals to enable them to move forward. There is a need for Australian educational policy to fill the vacuum in relation to re-entry into second chance education to ensure that the needs of this significant minority group are adequately addressed (Spierings 2003, Te Riele 2000, Wyn et al 2004). 


\section{Learning from international experience}

Interesting and informative points of comparison with exemplars from international practice may be able to provide Australian educators and local communities with fresh insights and strategies for addressing the needs of early school leavers. The Danish Production Schools (PS) are intended for young people who experience difficulties in making the transition from junior to middle and senior levels of schooling. These Production Schools exist alongside primary, senior secondary and technical schools. Operating under a discrete Act of Parliament, they are relatively independent and autonomous (Spierings 2003). Salient features of Production Schools include:

- Development of a renewed appetite for learning through the discipline of work

- Learning projects that result in real goods and services

- Student responsibility for learning and the conditions under which learning occurs

- A holistic approach to learning that includes the personal, social and educational situation of each student

- Diversity of workforce that includes trained teachers, tradespeople, professionals etc.

- Operation over 52 weeks rather than school terms or semesters.

Findings related to the destination outcomes of students suggest a positive trend that includes successful transitions into the workforce and into further education and training. A useful comparison of the PS system to the Australian context may help in identifying key issues for policy consideration in Australia. It may be argued that educational inclusion is an essential ingredient in Danish educational policy. Government support for this educational model ensures that it forms an integral part of the education system and co-exists amidst other educational settings as a genuine pathway rather than an adjunct (Spierings 2003).

Current educational policy debate in the Netherlands in favour of sideways movement as against vertical progression paths in education appears to reflect a growing recognition of the multidimensional nature of youth transitions. This is supported by the advocacy of joined-up policy making that incorporates multi-agency interventions to address the variety of incidents that influence a young person's transition (de Bruijn \& Voncken 1998, Nijhof 2001). The importance of inter-agency support and community networks is gaining increasing support in Australia. This is reflected in policy documents and reports (Kirby 2000, Prime Minister's Youth Pathways Action Plan Taskforce 2001). However, a more structured approach to establishing connections with broader community networks and support agencies is required both at the organisational level and at the classroom level. 
A good example of a systematic and cross-sectoral approach that facilitates the smoothness of youth transitions is demonstrated through the Scandinavian model. Local government responsibility for the development of a community base of service providers and agencies ensures the availability of support mechanisms for young people within the community. Through the use of mentors and career counsellors, young people are linked with different educational providers and support services to ensure that their specific needs are addressed. Similar arrangements are available in Australia through various youth initiatives implemented by the State Governments. However local government investment in a collaborative model that channels the resources of community organisations and agencies for the benefit of young people are not well known (Wyn et al 2004).

In New Zealand, the inclusion of the Alternative Education Policy in official policy construction demonstrates government recognition of the importance of providing second chance opportunities for disenfranchised youth. Learning programs for this cohort are delivered in conjunction with a community provider often using a nonschool approach. The aim of the policy is for these students to re-enter the education system in a mainstream school. Of note is the increasing Maori community involvement in policy construction and the provision of alternatives (Spierings 2003).

In the Australian context the importance of community involvement and seeking input from students, parents and community elders, in the development and implementation of educational programs for indigenous youth is reflected in policy documents and educational practice (MCEETYA 1995, Budby 1994, Bourke, Rigby and Burden 2000, Day1994, Gray \& Beresford 2002, Partington, Godfrey \& Harrison 1997, Watson \& Roberts 1996). Findings from numerous case studies (Bourke et al 2000) on parental and community involvement in Aboriginal education highlight improvements in student attendance, participation and academic achievement. However, the need for a systemic approach to community involvement in all aspects and at all levels of the schooling process has been identified. This requires changes and modifications to existing organisational frameworks to accommodate the needs of local situations. Ongoing training, professional development and employment of indigenous staff have also been advocated as a means for furthering community involvement in education (Bourke et al 2000, Hughes \& Moore 1997).

Finally, a consideration of second chance education in Israel suggests some similarities with those offered in Australia. The external schools in Israel that target teenagers and young adults who have failed secondary school are analogous in some respects to the second chance colleges in Australia. They specialise in preparing students for the external matriculation examinations. The 'Mechinot', one-year university preparatory programs (Shavit et al 2001, p. 3) appear to share some features 
of the bridging programs offered by some universities in Australia. Germane to this discussion on second chance education are the recent findings on second chance mechanisms in Israel which suggest that while second chance opportunities may not offer their users 'upward mobility', they 'protect them from downward mobility' (Shavit et al 2001, p. 9). Similar trends have been found in recent studies on the outcomes of enabling programs in Australia. Findings indicate that completion of an 'enabling program' often facilitated transition into the workforce and into further education (Dawe 2004, Phan \& Ball 2001).

\section{Conclusions}

It is clear that the opportunity for second chance education is crucial for groups of young people with disrupted educational pathways. Despite having left school early for a variety of reasons young people still retain educational aspirations. Findings from the case studies of second chance education in New South Wales, Victoria and South Australia indicate that the chief reason for re-entry was to complete secondary education and undertake further education. All the young people in the study believed that gaining an educational credential would enhance their futures (Wyn et al 2004).

The re-entry of early school leavers through the TAFE sector is strongly supported by the literature. Results of early school leaver destination data in 2001 show that nearly $51 \%$ of early school leavers indicated TAFE as the preferred destination (ABS 2001, Ferber 1999, Phan \& Ball 2001, Smyth \& Hattam 2004, Wyn et al 2004). More recent findings in PISA, Programme for International Student Assessment (2004) indicate that TAFE figured prominently in the educational aspirations of both indigenous and nonindigenous students. Nearly $20 \%$ of non-indigenous students aspired to obtaining a TAFE certificate or diploma. While about $13 \%$ of Indigenous students did not intend to pursue further education after secondary school, $40 \%$ of indigenous males planned to finish an apprenticeship and 30\% of indigenous females planned to complete a TAFE certificate (De Bortoli \& Cresswell 2004).

There are significant issues that need to be addressed to facilitate the effective transition of young people who wish to complete their education outside the traditional school environment. Table $\mathrm{V}$ presents an overview of the issues and the implications for policy makers, education and training providers and researchers, reframing issues already identified (McIntyre \& Melville 2000, Vinson 2001, Wyn et al 2004) into a model supporting transition to second chance education. 


\begin{tabular}{|c|c|}
\hline Issues & Implications \\
\hline \multicolumn{2}{|l|}{ Policy makers } \\
\hline \multirow{4}{*}{$\begin{array}{l}\text { Policy response to facilitate } \\
\text { effective re-entry into } \\
\text { second chance education }\end{array}$} & $\begin{array}{l}\text { - The needs of young people with disrupted educational pathways are } \\
\text { recognised and addressed in official education and training policy. }\end{array}$ \\
\hline & $\begin{array}{l}\text { - Effective policy on structured re-entry into second chance education } \\
\text { and/or training for non-completers is developed and implemented. }\end{array}$ \\
\hline & $\begin{array}{l}\text { - An organised structure of second chance education and training options } \\
\text { with clear pathways that facilitate entry and exit is developed and } \\
\text { implemented. }\end{array}$ \\
\hline & $\begin{array}{l}\text { - Efficient funding models that enable education providers, government } \\
\text { departments and community agencies to achieve the collective goals of } \\
\text { education and support services for young people are developed and } \\
\text { implemented. }\end{array}$ \\
\hline
\end{tabular}

\section{Education/training providers}

Systemic support services

- Support mechanisms to assist young people during crucial transition phases i.e. early exit from school, re-entry into second chance education, progression to higher education or employment are provided.

- The movements of students are monitored and tracked in a systematic manner. This includes departure from and re-entry into education and transitions between, within and out of educational institutions.

- Cross sectoral service agreements with government departments that include health and community services, local community agencies and employer networks are implemented to ensure on-going support for noncompleters.

- Relevant professional development for teachers is provided with a focus on the development of appropriate behaviour management skills, learning paradigms and assessment practices that cater to the different learning styles of young people.

\section{Researchers}

Knowledge about young people's priorities and interests

Structured re-entry into education and/or training

Efficient models of interagency collaboration

Longitudinal studies of early school leavers

Program development for second chancers
- The use of participatory research for the development of a knowledge database on the multi-dimensional transitions of young people to inform educational policy construction and practice.

- Models of re-entry and re-engagement that ensures consistency and improves the quality of the re-engagement process for non-completers are investigated.

- Best practice models based on collaborative partnership agreements, systematic brokering arrangements and optimal use of existing resources are investigated and documented.

- A systematic database on the short and long term outcomes of re-entry programs is developed and utilised to assist in policy formation.

- Development of innovative learning programs that integrate the art, the media and information communication technologies are developed and implemented to enhance the learning experience of young people.

\section{Table V \\ Issues and implications associated with re-entry into second chance education}


The literature contains strong messages about the value placed by young people on second chance education opportunities. The way forward is for educational policy to provide clear directions on the re-engagement and re-entry processes for noncompleters who wish to re-connect with learning. At the local level, links between schools, TAFE colleges, ACE providers and community agencies are seen to be crucial in facilitating an easy transition and enhancing the quality of the early school leaver's re-engagement with education.

\section{References}

Ainley, M. (1993) Styles of engagement with learning: multidimensional assessment of their relationship with strategy use and school achievement, Journal of Educational Psychology, vol. 85, no. 3, pp. 395-405.

Ainley, J. \& M. Sheret (1992) Progress through High School: A Study of Senior Schooling in New South Wales, Research Monograph no. 43, Australian Council for Educational Research, Melbourne.

Aldridge, F. \& P. Lavendar (2000) The Impact of Learning on Health, National Organisation for Adult Learning and National Institute of Adult Continuing Education, England and Wales, Leicester.

Alexander, K. L., D. R. Entwisle \& L. S. Olson (2001) Schools, achievement and inequality: a seasonal perspective, Educational Evaluation and Policy Analysis, vol. 23, pp. 171-191.

Anderson, D. (1985) Access to TAFE: Some Issues and Concerns, Victorian TAFE Papers, no. 3, October, pp. 53-56.

Arnot, M., J. Gray, M. James, J. Rudduck \& G. Duveen (1998) Recent Research on Gender and Educational Performance, The Stationery Office/OfSTED, London.

Astone, N. \& S. McLanahan (1991) Family structure, parental practices, and high school completion, American Sociological Review, vol. 56, pp. 309-320.

Audas, R. \& J. Willms (2001) "Engagement and Dropping out of School: A Life Course Perspective", Human Resources Development, Canada, Retrieved: 29 December, 2001 from http://www.hrdc-drhc.gc.ca/sp-ps/arb-dgra/publications.

Australian Bureau of Statistics (2001) Education and Work, Australia, Cat. No. 6227.0. ABS, Canberra.

Australian Bureau of Statistics (2001) "Education and Work", Retrieved: 23 September, 2004 from www.abs.gov.au.

Australian Bureau of Statistics (2000) Education and training experience, Australia. Cat. No. 6278.0. ABS, Canberra.

Australian Education Union TAFE Division (2001), "Policy on the role of TAFE in education", Retrieved: 23 September, 2004 from

http://www.aeufederal.org.au/Tafe/roleoftafepolicy.pdf. 
Australian National Training Authority (2003) "Shaping our future: Australia's national strategy for vocational education and training 2004 - 2010", Retrieved: 17 March, 2004 from http://www.anta.gov.au/dapStrategy.asp.

Ball, K. \& S. Lamb (2001) "Participation and achievement in VET of non-completers of School", Longitudinal Surveys of Australian Youth, Research Report Number 20, Australian Council for Educational Research, Retrieved: 10 February, 2005 from http://www.acer.edu.au.

Ball, S., M. Maguire \& S. Macrae (2000) Space, work and the 'new urban economies', Journal of Youth Studies, vol. 3, no. 3, pp. 279-300.

Bagshaw, B. \& R. Brown (2001) Young people of school age in TAFE, National Centre for Vocational Education Research, Australia.

Barrington, B. \& B. Hendricks (1989) Differentiating characteristics of high school graduates, dropouts and non-graduates, Journal of Educational Research, vol. 82, pp. 309-19.

Beavis, A., M. Murphy, J. Bryce \& M. Corrigan (2004) "Aspirations, expectations and implementation: A report prepared for The Smith Family", ACER, Retrieved: 20 February, 2005 from www.smithfamily.com.au.

Beck, U. (1992) Risk Society: Towards a New Modernity, (M. Ritter, Trans.), Sage Publications, London.

Beresford, Q. (1993) The really hard cases: a social profile and policy review of early school leaving, Youth Studies Australia, vol. 12, no. 4, pp. 14-25.

Bloomer, M. \& P. Hodkinson (2000) Learning careers: continuity and change in young people's dispositions to learning, British Educational Research Journal, vol. 26, no. 5, pp. 583-597.

Boomer, G. (1987) Who Skilled Cock Robin? Skilling Australia: The Role of Education, Address to the South Australian Association of State School Organisations, October.

Bourdieu, P. (1986) The forms of capital, in J.E. Richardson, ed., Handbook of Theory of Research for the Sociology of Education, Greenwood Press, London.

Bourke, C. J., K. Rigby \& J. Burden (2000, July) "Better practice in school attendance: improving the school attendance of Indigenous students", Retrieved: March 4, 2004 from http://www.detya.gov.au/schools/publications/2000/Attend_Synth.pdf

Broadbent, R. (2001) "The public role of TAFE: A position paper for Education for Work", In partnership with Victoria University Institute for Youth, Education and Community, Retrieved: 10 September, 2004 from http://www.iyec.com/public\%20role\%20of\%20tafe\%20paper\%202001.pdf.

Brown, J., R. Holdsworth \& H. Stokes (2001) "Building relationships: Making education work", Commonwealth Department of Education, Training and Youth Affairs, Canberra, Retrieved: 30 November, 2001 from http://www.detya.gov.au/schools/publicat.htm.

Budby, J. (1994) Aboriginal and Islander views: Aboriginal parental involvement in education, The Aboriginal Child at School, vol. 22, no. 2, pp. 123-128. 
Business Council of Australia (2003, January) "The cost of dropping out: The economic impact of early school leaving", Retrieved: 29 April, 2003 from http://www.bca.com.au

Bynner, J. \& K. Roberts (1991) Youth and Work: Transitions to Employment in England and Germany, Anglo-German Foundation, London.

Carbonaro, W. J. (1998) A little help from my friend's parents: Intergenerational closure and educational outcomes, Sociology of Education, vol. 71, pp. 295-313.

Carpenter, A. (2004) Creating the Future for Our Young People: Raising the school leaving age, Government of Western Australia.

Cohen, P. \& P. Ainley (2000) In the country of the blind?: Youth studies and cultural studies in Britain, Journal of Youth Studies, vol. 3, no. 1, pp. 79-95.

Coleman, J. S. (1988) Social capital in the creation of human capital, American Journal of Sociology, vol. 94, pp. S95-S120.

Craven, R., A. Tucker, G. Munns, J. Hinkley, H. Marsh \& K. Simpson (2003) Indigenous Students' Aspirations: Dreams, perceptions, and realities, Commonwealth Department of Education, Science, and Training, Canberra.

Curtin, R (2003) "How young people are faring", Dusseldorp Skills Forum, Retrieved: 7 July, 2004 from http://www.dsf.org.au/papers/108/How_Young_Faring_AUG2003_0.pdf.

Dawe, S. (2004) Moving On From Enabling Courses: Why do some students remain in enabling courses? National Centre for Vocational Education Research, Australia.

Day, A. (1994) Looking toward high school: Aboriginal students and parents make choices, in S. Harris \& M. Malin, eds., Aboriginal Kids in Urban Classrooms, Social Science Press, Wentworth Falls, NSW.

De Bortoli, L. \& J. Cresswell (2004) "Australia's Indigenous Students in PISA 2000: Results From an International Study", Australian Council for Educational Research Monograph No 59, Retrieved: 20 February, 2005

www.acer.edu.au/research/PISA/documents/RM59IndigScreen.pdf.

De Bruijn, E. \& E. Voncken (1998) The Netherlands, in OECD, eds., Pathways and Participation in Vocational and Technical Education and Training, OECD, Paris.

Dench, S. \& J. Regan (2000) "Learning in Later Life: Motivation and Impact", Institute for Employment Studies, Report commissioned by the Department for Education and Employment, Research Report Number 183, Retrieved: 30 September, 2003 from http://www.employment-studies.co.uk/summary/summary.php?id=rr183.

Dwyer, P. (1996) Early School Leavers and the Degeneration of Youth Policy, National Clearinghouse for Youth Studies, Tasmania.

Dwyer, P. \& K. Wyn (1998) Post-compulsory education policy in Australia and its impact on participant pathways and outcomes in the 1990s, Journal of Education Policy, vol. 13, no. 3, pp. 285-300.

Dwyer, P., J. Wyn, B. Wilson \& F. Stewart (1990) Early School Leavers, Youth Research Centre, Victoria. 
Ekstrom, R. B., M. E. Goertz, J. M. Pollack \& D. A. Rock (1986) Who drops out of high school and why? Findings from a national study, Teachers College Record, vol. 87, pp. 356-373.

Eldridge, D. (2001) Footprints to the Future: Report from the prime minister's youth pathways action plan taskforce, AusInfo, Canberra.

Emirbayer, M., \& M. Mische (1998) What is agency? American Journal of the Sociology of Education, vol. 103, no. 4, pp. 964-1022.

Entwisle, D. R., K. L. Alexander \& L. S. Olson (1997) Elementary School Organization. Children, Schools, and Inequality, Westview Press, Boulder CO.

European Group for Integrated Social Research (2001) Misleading trajectories: Dilemmas of young adults in Europe, Journal of Youth Studies, vol. 4, no. 1, pp. 101-118.

Evans, K. (2002) Taking control of their lives? Agency in young adult transitions in England and the New Germany, Journal of Youth Studies, vol. 5, no. 3, pp. 245-269.

Evans, K. \& A. Furlong (1997) Metaphors of youth transitions: Niches, pathways, trajectories or navigations, in J. Bynner, K. Evans \& A. Furlong, eds., Youth, Citizenship and Social Change in a European Context, Aldershot, Ashgate.

Evans, K. \& W. Heinz (1994) Becoming Adults in England and Germany, AngloGerman Foundation, London.

Ferber, J. (1999) Vocational Education and Training Programs for Young People at Risk, National Centre for Vocational Education Research, Australia.

Fine, M. (1996) Introduction, in D. Kelly \& J. Gaskell, eds., Debating Dropouts: Critical Policy and Research Perspectives on School Learning, (pp. xi-xviii), Teachers College Press, New York.

Finn, J. D. (1989) Withdrawing from school, Review of Educational Research, vol. 59, pp. 117-142.

Fraser, N. (1989) Unruly Practices: Power, Discourse and Gender in Contemporary Social Theory, University of Minnesota Press, Minneapolis.

Freire, P. (1970) Pedagogy of the Oppressed (M. Ramos, Trans.), Seabury, New York.

Furlong, A. \& F. Cartmel (1997) Young People and Social Change: Individualization and Risk in Late Modernity, Open University Press, Buckingham.

Gardiner, G. (1996) School to Street: The Aboriginal Youth Experience in Victoria, Monash University Koorie Research Centre, Melbourne.

Giddens, A. (1991) Modernity and Self-identity: Self and society in the late modern age, Polity Press, Cambridge.

Goldschmidt, P. \& J. Wang (1999) When can schools affect dropout behavior? A longitudinal multi-level analysis, American Educational Research Journal, vol. 36, pp. $715-738$.

Gray, J. \& Q. Beresford (2001) Alienation from School Among Aboriginal Students, Institute for the Service Professions, Edith Cowan University, Perth. 
Gray, J. \& Q. Beresford, Q (2002) Aboriginal non-attendance at school: Revisiting the Debate, Australian Educational Researcher, vol. 29, No. 1, April 2002, pp. 27-42.

Green, A. (1991) The reform of post-16 education and training and the lessons from Europe, Journal of Education Policy, vol. 6, no. 3, pp. 327-339.

Green, E., W. Mitchell, \& R. Bunton (2000) Contextualizing risk and danger: An analysis of young people's perceptions of risk, Journal of Youth Studies, vol. 3, no. 2, pp. 109-126.

Grossberg, L. (1996) Identity and cultural studies: Is that all there is?, in S. Hall \& P. Du Gay, eds., Questions of Cultural Identity, Sage, London.

Harvey, D. (1993) From space to place and back again: Reflections on the condition of postmodernity, in J. Bird, ed., Mapping the Futures: Local cultures, global change. Routledge, London.

Henry, B. \& N. Roseth (1985) School and Beyond: School leavers' perceptions of the relevance of secondary education, NSW Department of Education, Sydney.

Holden, E. (1993) Services and Early School Leavers: Policies, programs and practices, Youth Research Centre, Institute of Education, University of Melbourne, Victoria.

Holden, E. \& P. Dwyer (1992) Making the Break: Leaving school early, Youth Research Centre, University of Melbourne, Parkville, Victoria.

House of Representatives Standing Committee on Employment, Education and Training (1996) Truancy and Exclusion from School: Inquiry into nonattendance at school by young people under fifteen years of age, Canberra.

Hughes, P \& A. J. Moore (1997) Aboriginal ways of learning and learning styles, Paper presented to the Annual Conference of AARE, December 1997, Brisbane.

Inbar, D. \& R. Sever (1989) The importance of making promises: An analysis of second-chance policies, Comparative Education Review, vol. 33, no. 2, pp. 232-242.

Janosz, M., M. LeBlanc, B. Boulerice \& R. Tremblay (1997) Disentangling the weight of school dropout predictors: A test on two longitudinal samples, Journal of Youth and Adolescence, vol. 26 no. 6, pp. 733-62.

Kangan, M (Chair) (1974) TAFE in Australia: Report on needs in technical and further Education, (Kangan Report), Australian Committee on Technical and Further Education, AGPS, Canberra.

Kaplan, D. S., B. M. Peck \& H. B. Kaplan (1997) Decomposing the academic failuredropout relationship: A longitudinal analysis, The Journal of Educational Research, vol. 90, pp. 331-343.

Karmel, T. (1995) Educational Expansion and Equity. Presented at the 24th Conference of Economists, Department of Employment, Education and Training, Canberra.

Kell, P. (1990, March) The 'Clever Country' and TAFE in NSW: A case study in marginalising access and equity. Presented at the NSW Teachers' Federation Conference, Managing Public Education: A Question of Balance, Sydney. 
King, C. (1987) Socio-economic Status, Educational Equity and TAFE Participation in the Sydney Metropolitan Area: Preliminary findings, NSW Department of TAFE Policy Unit, Sydney.

Kirby, P. (2000) Ministerial Review of Post-compulsory Education and Training Pathways in Victoria, Victorian Department of Employment, Education and Training, Melbourne.

Kysel, F., A. West \& G. Scott (1992) Leaving school: Attitudes, aspirations and destinations of fifth year leavers in Tower Hamlets, Educational Research, vol. 34, no.2, pp. 87-105.

Lamb, S. (1994) Dropping out of school in Australia: Recent trends in participation and outcomes, Youth and Society, vol. 26, no. 2, pp. 194-222.

Lamb, S., P. Dwyer \& J. Wyn (2000) "Non-completion of School in Australia: The changing patterns of participation and outcomes", Longitudinal Surveys of Australian Youth, Research Report Number 16, Australian Council for Educational Research, Retrieved: 10 April, 2005 from http://www.acer.edu.au.

Lamb, S., A. Walstab, R. Teese, M. Vickers \& R. Rumberger (2004) "Staying On At School: Improving student retention in Australia", Report for the Queensland Department of Education and the Arts, Centre for Post-compulsory Education and Lifelong Learning, The University of Melbourne, Retrieved: 10 April, 2005 from http://www.acer.edu.au.

Lamb, S., M. Long \& G. Baldwin (2002) Performance of the Australian Education and Training System, Report for the Victorian Department of Premier and Cabinet, Melbourne.

Lamb, S. \& P. McKenzie (2001) Patterns of Success and Failure in the Transition from School to Work in Australia, Report No. 18, Australian Council for Educational Research, Melbourne.

Lamb, S. \& R. Rumberger (1999) "The Initial Work and Education Experiences of Early School Leavers: A comparative study of Australia and the United States", Longitudinal Surveys of Australian Youth, Research Report Number 14, Australian Council for Educational Research, Retrieved: 4 April, 2005 from http://www.acer.edu.au.

Lechte, J. (1985) PEP in TAFE: What does it mean? What can it mean? Victorian TAFE Papers, No. 2, April, pp. 9-12.

Leong, K. (2002) "Re-engaging with learning: Early school leavers and VET", Retrieved: 21 January, 2005 from

www.avetra.org.au/abstracts_and_papers_2002/leong.pdf.

Lewis, P. \& P. Koshy (1999) Youth employment, unemployment, and school participation, Australian Journal of Education, vol. 43, no. 1, pp. 42-57.

Lloyd, D. N. (1978) Prediction of school failure from third grade data, Educational and Psychological Measurement, vol. 38, no. 4, pp. 193-200. 
MacDonald, H. (1999) Bridging the Gap. Assisting early school leavers to make the transition to work, Brotherhood of St Laurence, Fitzroy, Victoria.

MacDonald, R. \& J. Marsh (2001) Disconnected Youth? Journal of Youth Studies, vol. 4, no. 4, pp. 373-391.

MacDonald, A., L. Saunders \& P. Benefield (1999) Boys' achievement, progress, motivation and participation: Issues raised by the recent literature, National Foundation for Educational Research, Slough.

Marginson, S. (1993) Education and Public Policy in Australia, Cambridge University Press, Cambridge.

Marks, G. \& N. Fleming (1999) Early School Leaving in Australia, Australian Council for Educational Research, Melbourne.

Marks, G., N. Fleming, M. Long \& J. McMillan (2000) "Patterns of Participation in Year 12 and Higher Education in Australia: Trends and Issues", Longitudinal Surveys of Australian Youth, Research Report Number 17, Australian Council for Educational Research, Retrieved: 8 April, 2005 from http://www.acer.edu.au.

Maychell, K. \& C. Evans with R. Brooks, B. Lee \& S. Pathak (1998) Leaving at 16: A study of factors affecting young people's decision to leave full-time education, National Foundation for Educational Research, Slough.

MCEETYA (1995) National Strategy for the Education of Aboriginal and Torres Strait Islander Peoples 1996-2002, Victoria, Australia.

McFadden, M. (1996) 'Second chance' education: Accessing opportunity or recycling disadvantage? International Studies in Sociology of Education, vol. 6, no. 1, pp. 87-111.

McInerney, D. (1991) Key determinants of motivation of non-traditional Aboriginal students in school settings: Recommendations for educational change, Australian Journal of Education, vol. 35, no. 2, pp. 154-174.

McIntyre, J., J. Freeland, B. Melville \& C. Schwenke (1999) Early School Leavers at Risk, National Centre for Vocational Education Research, South Australia.

McIntyre, J. \& B. Melville (2000) "Early School Leavers in the Community", UTS Research Centre for Vocational Education and Training, Retrieved: 10 September, 2004 from http://www.oval.uts.edu.au/working_papers/2000WP/0005mcintyre.pdf.

McMillan, J. \& G. Marks (2003) "School leavers in Australia: Profiles and pathways", Longitudinal Surveys of Australian Youth, Research Report Number 31, Australian Council for Educational Research, Retrieved: 8 April, 2005 from http://www.acer.edu.au.

McNeal, R. B. (1999) Parental involvement as social capital: Differential effectiveness on science achievement, truancy, and dropping out, Social Forces, vol. 78, pp. 117-144.

Mead, L. (1997) The rise of paternalism, in L. Mead, ed., The New Paternalism: Supervisory Approaches to Poverty, (pp. 1-38), Brookings Institution Press, Washington DC. 
Mulcahy, D. (2002) "New management in VET: Working commerce and community together?", Department of Education Policy and Management, University of Melbourne, Retrieved: 23 September, 2004 from

http://www.avetra.org.au/abstracts_and_papers_2002/mulcahy.pdf.

Munns, G. \& M. McFadden (2000) First chance, second chance or last chance? Resistance and response to education, British Journal of Sociology of Education, vol. 21, no. 1, pp. 59- 76.

Murray-Smith, S. (1966) Technical education: The lines of development, in K. Sanders, ed., Technical Education for Development, University of Western Australia Press, Perth.

Murray-Smith, S. (1971) Technical education, in A. G. Maclaine and R. Selby-Smith, eds., Fundamental Issues in Australian Education, Novak, Sydney.

Nijhof, W. (2001) The VET system between private demands and public interests: The Dutch challenge, in L. Nieuwenhuis \& W. Nijhof, eds., The Dynamics of VET and HRD Systems, Twente University Press, Enschede.

Noonan, P. (1985) Participation and Equity Programs in TAFE. A Critical Analysis, TAFE National Centre for Research and Development, Adelaide.

Ogbu, J. U. (1992) Understanding cultural diversity and learning. Educational Researcher, vol. 21, pp. 5-14.

Partington, G., J. Godfrey \& H. Harrison (1997) "Perspectives on Retention of Aboriginal Students", Retrieved: 4 March, 2004 from

http://www.eddept.wa.edu.au/able d/quality/retention\%20of\%Abl\%20Ss\%201997.html.

Phan, O. \& K. Ball (2001) Outcomes from Enabling Courses, National Centre for Vocational Education Research, Australia.

Pitman, J. \& P. Herschell (2002) The Senior Certificate: A new deal, Queensland Department of Education, Brisbane.

Powles, M. \& D. Anderson (1996) In the balance: Participation and access in TAFE. Presented at Educational research: Building new partnerships, Conference jointly organised by Education Research Association, Singapore and Australian Association for Research in Education, Singapore Polytechnic, Singapore, November 1996.

Prime Minister's Youth Pathways Action Plan Taskforce (2001) "Report from the Prime Minister's Youth Pathways Action Plan Taskforce. Footprints to the Future", Commonwealth Department of Education, Training and Youth Affairs, Retrieved: 18 August, 2004 from http://www.youthpathways.gov.au.

Raffe, D. (2003) Pathways linking education and work: A review of concepts, research, and policy debates, Journal of Youth Studies, vol. 6, no. 1, pp. 3-18.

Raffo, C. \& M. Reeves (2000) Youth transitions and social exclusion: Developments in social capital theory, Journal of Youth Studies, vol. 3, no. 2, pp. 147-166.

Roberts, K. (1968) The entry into employment: An approach towards a general theory, Sociological Review, vol. 16, no. 2, pp. 165-184. 
Roman, L. (1996) Spectacle in the dark: Youth as transgression, display, and repression, Educational Theory, vol. 46, no. 1, pp. 1-22.

Rothman, S. (2002) Student absence in South Australian schools, Australian Educational Researcher, vol. 29, no. 1, pp. 69-92.

Rudd, P. \& K. Evans (1998) Structure and agency in youth transitions: Student experiences of vocational further education, Journal of Youth Studies, vol. 1, no. 1, pp. 39-62.

Rumberger, R. (2001) Why students drop out of School and what can be done. Paper prepared for the conference Dropouts in America: How Severe is the Problem? Harvard University, January 13, 2001.

Rumberger, R. W. \& K. A. Larson (1998) Student mobility and the increased risk of high school drop out, American Journal of Education, vol. 107, pp. 1-35.

Rumberger, R. (1983) Dropping out of high school: The influence of race, sex, and family background, American Educational Research Journal, vol. 20, pp. 199-210.

Rumberger, R. W. (1995) Dropping out of middle school: A multi-level analysis of students and schools, American Educational Research Journal, vol. 32, pp. 583- 625.

Saunders, J., M. Jones, K. Bowman, P. Loveder \& L. Brooks (2003) "Indigenous People in Vocational Education and Training: A statistical review of progress", Retrieved: 12 September, 2004 from

http://www.ncver.edu.au/research/commercial/op298.pdf.

Schofield, K. (2001) Vocational Education and Training: Lessons Learned, Education for Work Conference Proceedings, Victoria.

Scott, B. (Chair) (1990) TAFE's Commission for the 1990s: Restructuring vocational, basic and adult education in NSW (Scott Report), Report of the Management Review, NSW Education Portfolio, June.

Shavit, Y., H. Ayalon \& M. Kurleander (2001) "Second-chance Education and Inequalities in Israel", Retrieved: 23 September, 2004 from http://www.mzes.uni-mannheim.de/rc28/papers/shavit_etal_f.doc.

Smyth, J. \& R. Hattam (2004) 'Dropping Out', Drifting Off, Being Excluded: Becoming somebody without school, Peter Lang Publishing Inc., New York.

Smyth, J., R. Hattam, J. Cannon, J. Edwards, N. Wilson \& S. Wurst (2000) Listen to Me I'm Leaving: Early school leaving in South Australian secondary schools, Flinders Institute for the Study of Teaching, Department of Education, Training and Employment and Senior Secondary Assessment Board of South Australia, South Australia.

Spierings, J. (2003) "Learning alternatives: A last chance or a real choice?" Dusseldorp Skills Forum, Retrieved: 10 September, 2004 from http://www.dsf.org.au/papers/113/LAlt_SSp_SEP03_0.pdf.

Steinberg, L., S. M. Dornbusch \& B. B. Brown (1992) Ethnic differences in adolescent Achievement, American Psychologist, vol. 47, pp. 723-729.

Stokes, H. (2000) Out of Education, Department of Education, Employment and Training, Victoria. 
Sturman, A. (1985) Immigrant Australians and Education, Australian Educational Review, vol. 22. ACER, Melbourne.

Sukhnandan, L. (1999) An Investigation into gender differences in achievement. Phase 1: A review of recent research and LEA information on provision, National Foundation for Educational Research, Slough.

Swanson, C. B. \& B. Schneider (1999) Students on the move: Residential and educational mobility in America's schools, Sociology of Education, vol. 72, pp. 54-67.

Sweet, R. (1985) Access and selection issues revisited, Australian Journal of TAFE Research and Development, vol. 1, no.1, pp. 89-95.

Teachman, J. D., K. Paasch \& K. Carver (1996) School capital and dropping out of school, Journal of Marriage and the Family, vol. 58, pp. 773-783.

Teese, R. (2002) Early leaving in Victoria: Geographical patterns, origins, and strategic issues. Educational Outcomes Research Unit, University of Melbourne, Melbourne.

Teese, R. \& J. Polesel (2003) Undemocratic Schooling: Equity and quality in mass secondary schooling in Australia, Melbourne University Press, Melbourne.

Teese, R., J. Polesel, K. O’Brien, B. Jones, M. Davies, A. Walstab \& A. Maughan (2000) Early School Leaving: A review of the literature, Centre for Post-Compulsory Education and Training, University of Melbourne/RMIT University, Parkville.

Te Riele, K. (2000) “The Best Thing I've Ever Done: Second chance education for early school leavers", AARE Conference, University of Sydney, Retrieved: 15 September, 2004 from http://www.aare.edu.au/00pap/ter00203.htm.

Varlaam, A. \& A. Shaw (1984) Attitudes to school: a study of fifth year pupils, Improving Secondary Schools (Hargreaves Report), Inner London Education Authority, London.

Vinson, T. (2001) "Public Education Inquiry NSW, Third Report" Retrieved: 10 September, 2004 from http://www.pub-ed-inquiry.org/reports/final_reports/04/CH20_51.html.

Walker, J. C. (1987) School, Work and the Problems of Young People: A cultural approach to curriculum development, Curriculum Development Centre, Canberra.

Walker, J. C. (1995) Educating teenagers, Forum of Education, vol. 50, pp. 39-48.

Watson, K. \& D. Roberts (1996) Promoting home-community-school links, Australian Journal of Indigenous Education, vol. 24, no. 1, pp. 1-5.

Western Australian Department of Education and Training (2003) "Establishment of the Department of Education and Training: Implementation process", (February 3), Retrieved: 6 March, 2004 from http://www.det.wa.gov.au/docs/edu-training-implementation.doc.

White, R. \& J. Wyn (2004) Youth and Society: Exploring the social dynamics of youth experience, Oxford University Press, Australia.

White, R. \& J. Wyn (1998) Youth agency and social context, Journal of Sociology, vol. 34, no. 3, pp. 314-327. 
Williams, T. (1987) Participation in Education, Australian Council for Educational Research, Hawthorn, Victoria, pp. 15-16.

Williams, T., M. Long, P. Carpenter \& M. Hayden (1993) Year 12 in the 1980s, Australian Government Publishing Service, Canberra.

Willis, P. (1977) Learning to Labor: How working class kids get working class jobs, Columbia University Press, New York.

Wooden, M. (1996) The youth labour market: Characteristics and trends, Australian Bulletin of Labour, vol. 22, no. 2, pp. 137-60.

Wyn, J. \& P. Dwyer (1999) New directions in research on youth in transition, Journal of Youth Studies, vol. 2, no. 1, pp. 5-21.

Wyn, J. \& P. Dwyer (2000) New patterns of youth transition in education, International Social Science Journal, vol. 164, pp. 147-159.

Wyn, J., H. Stokes \& D. Tyler (2004) "Stepping Stones: TAFE and ACE program development for early school leavers", NCVER, Retrieved: 1 August, 2004 from http://www.ncver.edu.au/research/proj/nroo15.pdf.

Wyn, J. \& R. White (1997) Rethinking Youth, Allen \& Unwin, Australia.

Yogev, A. (1997) Second chance education and alternative routes, in L. Saha, ed., International Encyclopedia of the Sociology of Education, Pergamon, New York. 